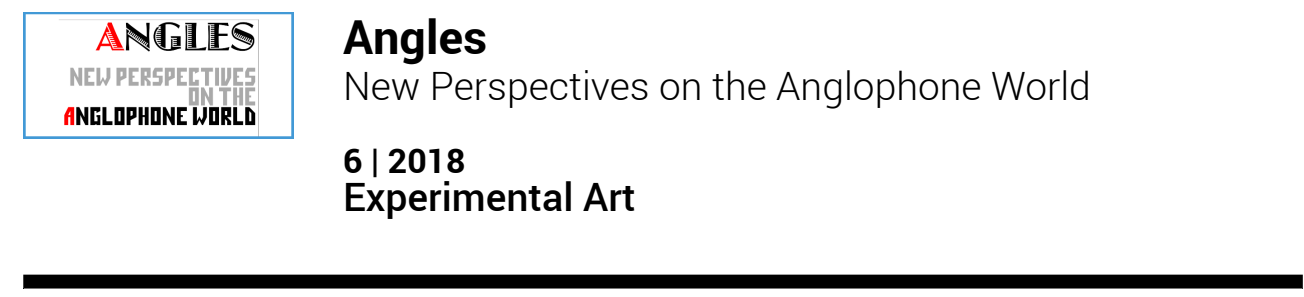

\title{
What Do We Mean by Experimental Art?
}

\section{Derek Attridge}

\section{(2) OpenEdition \\ Journals}

Electronic version

URL: https://journals.openedition.org/angles/962

DOI: 10.4000/angles.962

ISSN: 2274-2042

\section{Publisher}

Société des Anglicistes de l'Enseignement Supérieur

\section{Electronic reference}

Derek Attridge, "What Do We Mean by Experimental Art?", Angles [Online], 6 | 2018, Online since 01 April 2018, connection on 06 June 2022. URL: http://journals.openedition.org/angles/962 ; DOI: https://doi.org/10.4000/angles.962

This text was automatically generated on 6 June 2022

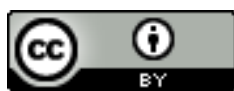

Angles est mise à disposition selon les termes de la Licence Creative Commons Attribution 4.0 International. 


\title{
What Do We Mean by Experimental Art?
}

\author{
Derek Attridge
}

1 What exactly do we mean when we call a work of art experimental? And how does experimental art relate to non-experimental - but still successful - art in the eyes of those who use these terms? To explore this question, I would like to approach it from six different directions; if we can gain a sense of how the term is generally used, we may be in a position to advance to a more theoretically based account.

2 (1) "Experimental" may be understood purely on the basis of the scientific model. That is to say, art may be used to test various hypotheses, or artists and scientists may work together to produce results that aim to illuminate the nature of reality or instruct the general public. One of many such examples is the "Synergy Project: Light and Life", described on the project's website as follows:

Tristan and artist Shawn Towne set out to develop a novel means of conveying human impacts on sea grass beds through art based on light and movement. Their inspiration is derived from underwater video taken off the coast of Cape Cod, focusing on fragile, ephemeral eelgrass beds. These are locations where man's influence is driving rapid changes in the ecosystem, often for the worse.

Through their work together, they hope to communicate the degradation of these systems from coastal development, as well as provide a baseline view of particular ecological sites at a given point in time for potential scientific application. (Synergy Project)

However, this rather literal meaning is not what is usually meant by experimental art; the term may gain some authority from its overtones of hard science, but does not usually imply an actual engagement with science and scientists. The etymology of "experiment" takes us back to the Latin verb experiri, to test or try, and its associated noun experimentum, a trial, test, or proof; and the word in English of course predates the development of scientific method. (The earliest recorded examples of "experimental" mean "having experience of" or "based on experience" - and we may note that the French equivalent of "experiment" is expérience.) What does connect the modern scientific and artistic uses of the word is the sense of trial-and-error, of testing 
a hypothesis - but in the world of the arts, an experiment is not controlled in the same way as it is in scientific practice (a point I will come back to) nor is it a requirement that the experiment be repeatable by others.

4 (2) The experimental quality of art is more likely to be understood as a matter of degree of innovation. We do not use the label "experimental" for John Banville's Book of Evidence (1989) or Colm Tóibín's The Master (2004) or Margaret Atwood's Oryx and Crake (2003), though they are all outstanding examples of the novel form. We are more likely to apply the term to Eimear McBride's A Girl is a Half-Formed Thing (2013) or Will Self's Umbrella (2012) or Mark Z. Danielewski's House of Leaves (2000). McBride's and Self's novels announce in their first paragraphs that they are probing the limits of what is readable:

For you. You'll soon. You'll give her name. In the stitches of her skin she'll wear your say. Mammy me? Yes you. Bounce the bed, I'd say. I'd say that's what you did. Then lay you down. They cut you round. Wait and hour and day. (McBride 2013:1) I'm an ape man, I'm an ape-ape man ... Along comes Zachary, along from the porter's lodge, where there's a trannie by the kettle and the window is cracked open so that Muswell Hill calypso warms the cold Friern Barnet morning, staying with him, wreathing his head with rapidly condensing pop breath. (Self 2012: 1)

Danielewski's experimentation begins even earlier: the title page states: HOUSE OF LEAVES

by Zampanò

with introduction and notes by Johnny Truant (Danielewski 2000)

We may then notice that the page facing the title page has the words "MARK $\mathrm{Z}$. DANIELEWSKI'S" across from the title. And if we flip through the book, we encounter a host of different type faces, pages largely blank, print running sideways up the page, and so on. House of Leaves shows itself to be worthy of the adjective "experimental" even before we start reading the text. One problem with this approach is that it presents us with a spectrum, and a spectrum that has many works falling somewhere in the uncertain middle area. For instance, staying with novels, would Ali Smith's How to Be Both (2014) be considered experimental? It appears at first to be relatively conventional, but when the reader discovers halfway through the novel that it is starting again in a different century (and especially if she learns that had she picked up a different copy of the same book she might have read the two halves in the other order) the term "experimental" might seem appropriate. Or take Eleanor Catton's The Luminaries (2013). From one point of view it is a long, highly conventional narrative imitative of the three-decker Victorian novel; but when we take into account its form we may want to call it experimental: each of the many characters is associated with a zodiacal sign or heavenly body, each of the 12 parts opens with an astrological chart relevant to the date on which the events of that part occur, and the parts diminish in length in imitation of the waning moon.

This uncertainty about the middle ground perhaps does not matter; we can live with the idea of degrees of "experimentalness" and have no problem with the idea that one work is "highly experimental" while another is "somewhat experimental". More problematic is the effect of history and hindsight on this approach. Let us take Beethoven's "Eroica" symphony, for instance. In this work, first performed in 1805, 
Beethoven produced a highly radical piece of music which represented an immense challenge for its first listeners, who had heard nothing like it before. The composer, it must have seemed, was experimenting with the symphonic form. But we are unlikely to call it experimental today because of its place in the history of the symphony; Beethoven's innovations soon became accepted resources for composers, and even longer, more discontinuous, more harmonically daring symphonies were to follow. Or take Picasso's 1907 painting Les Demoiselles d'Avignon: this work broke all the rules of representational art, and yet its influence has been such that it now has a solid place within the history of art that renders the term "experimental" unlikely in current discussions. We tend not to think of T. S. Eliot's The Waste Land (1922) as experimental today, though Eliot certainly was experimenting with what could be done in poetry, nor of Le Corbusier's starkly simple villas of the nineteen-teens, though they were aesthetically revolutionary buildings, in both cases because their innovations gave rise to entire movements in their respective art forms.

It seems, then, when we take historical processes into account, the term "experimental" does not simply mean "degree of innovation." We need to complicate our approach to the idea of experimentation in art.

9 (3) The examples I have mentioned suggest that we are more likely to call something an experiment when it does not lay the foundations for a new movement, as the Eroica symphony, Les Demoiselles d'Avignon, The Waste Land, and Le Corbusier's villas did. We are more likely to use the term for a work of art whose innovations proved to be a dead-end, an artistic gamble that did not pay off. One body of poetry that still often gets called experimental is the series of attempts by a number of poets in England in the late sixteenth century to write vernacular verse in quantitative metres, imitative of Latin and Greek verse (as they understood it). Edmund Spenser, Sir Philip Sidney, Thomas Campion and many others tried to determine which syllables of English words were "long" and which "short" and to construct lines of verse on this basis; however, the nature of English speech, dominated by stress, not quantity, was unsuited to this method, and the craze soon died out. ${ }^{1}$ Readers voted with their eyes and ears, so to speak, and preferred the accentually-based verse of The Faerie Queene and Astrophel and Stella (not to mention the plays of the Elizabethan dramatists, who were wise enough not to meddle with the vernacular verse-forms they had inherited.) These attempts at quantitative English metre are often referred to simply as the "quantitative experiments". Other examples might be William Blake's experiments with colour printing, which did not stand the test of time, and the language invented by Ted Hughes and Peter Brook for their play Orghast, presented at Persepolis in 1971 but not used again. And no doubt there were innumerable experiments by artists of all kinds throughout history whose failure led to their being quietly set aside, and of which we are consequently unaware.

10 This seems a rather negative approach to experimentation in the arts, however; it more or less equates "experiment" with "failed experiment". It ought to be possible to speak of successful experiments, even in the past. We need to complicate our picture further.

11 (4) Perhaps we should put the emphasis on the size of the audience. Is experimental art always art of minority interest? How does it relate to the notion of the avant-garde, which usually implies art that appeals to only a small number?

12 It is certainly true that most examples of what we are likely to call experimental art do not have wide appeal, for reasons that are obvious. Arnold Schoenberg's second string 
quartet, written in 1908, in which the composer experimented with complete atonality for the first time, still does not draw large audiences. However, if what appears to be an experiment does in the course of time become popular, we may well cease to think of it as experimental - as with the examples by Beethoven, Picasso, Eliot and Le Corbusier mentioned earlier. But there are possible counter-examples. Late in his life, Matisse started creating works of art out of boldly coloured cut-out shapes in a manner that we might want to call experimental; Turner, also late in his career, experimented with swirls of colour to produce paintings that were abstract in all but name; Malevich conducted what are called "suprematist experiments" with blocks of colour or squares of black or white. Yet these three bodies of work were among the most popular exhibitions in London in the year 2014 - in fact, the Matisse cut-out show was Tate Modern's most popular show since the gallery's opening. Because these works did not become assimilated as central to major movements in art - what could follow Matisse's snail (Figure 1), Malevich's black square (Figure 2) or Turner's seascapes (Figure 3)? they have not suffered the same fate as the other examples; they still stand out as exceptional and experimental. ${ }^{2}$

Figure 1. Henri Matisse, The Snail (1952-3)

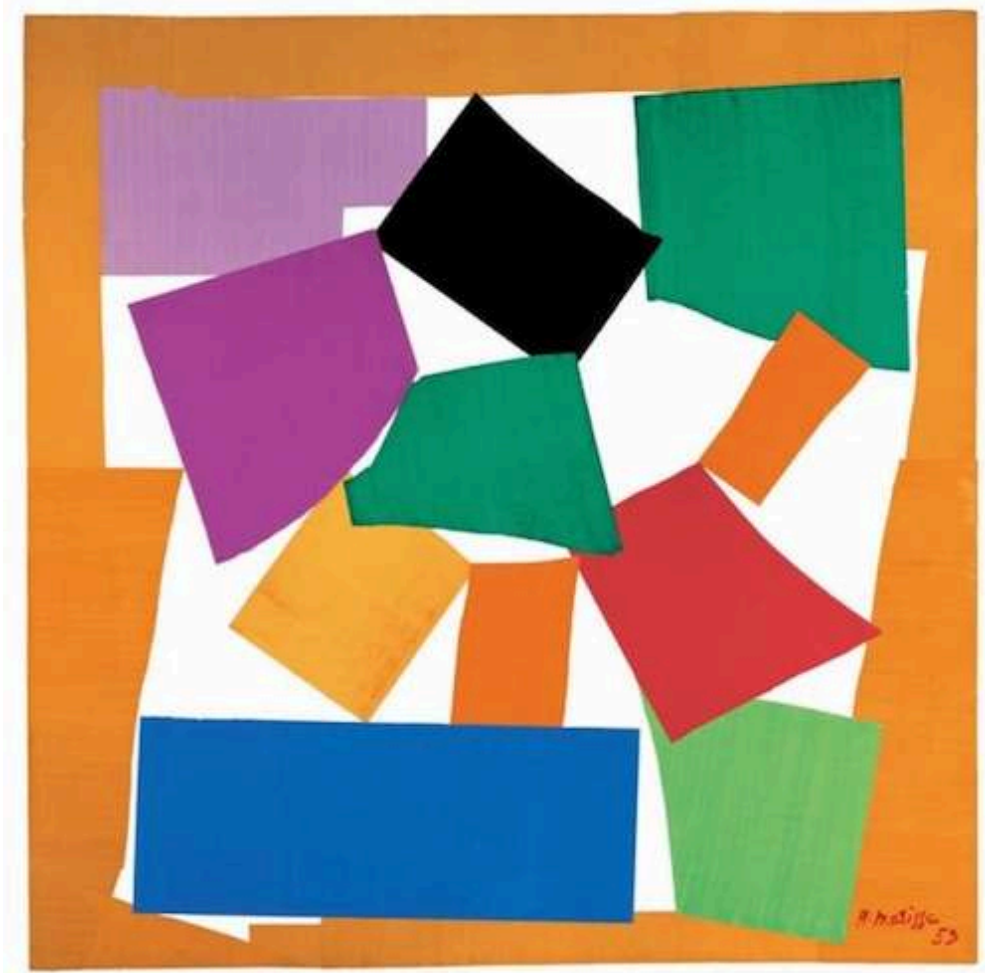

Source: http://www.independent.co.uk/arts-entertainment/art/reviews/henri-matisse-the-cut-outs-artreview-9259383.html\#gallery 
Figure 2. Kasimir Malevich, Black Square (1915)

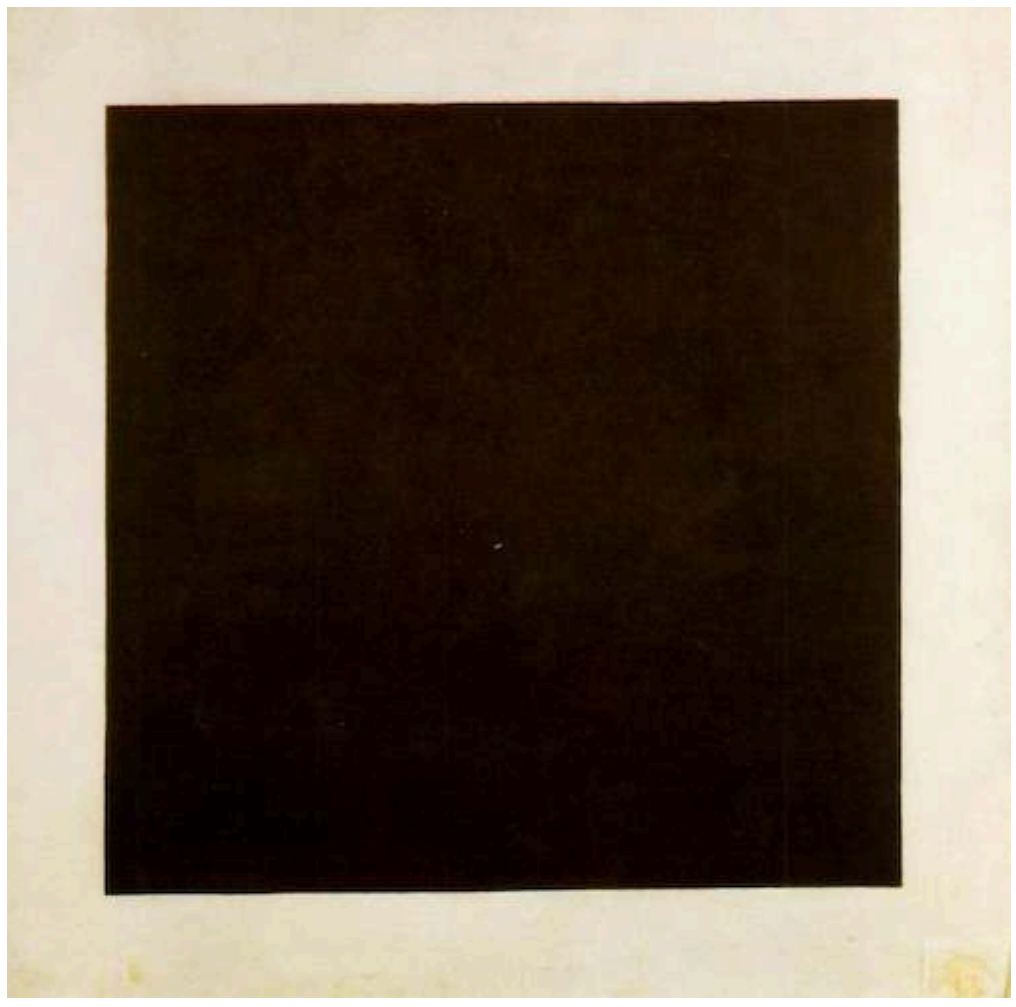

Source: http://www.tate.org.uk/art/research-publications/the-sublime/philip-shaw-kasimir-malevichsblack-square-r1141459

Figure 3. J. M. W. Turner, Seascape with Distant Coast (ca. 1840).

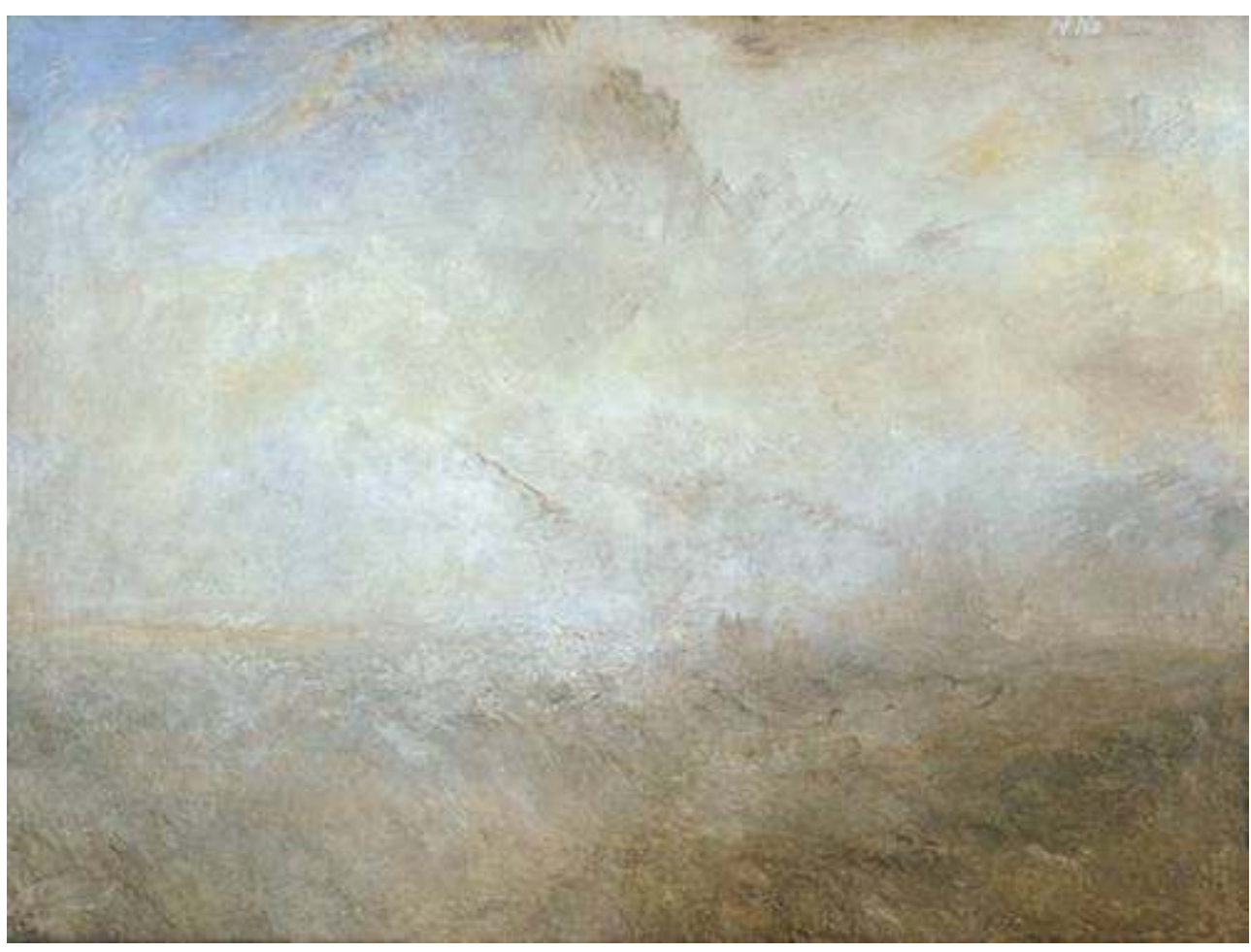

Source: http://www.tate.org.uk/art/artworks/turner-seascape-with-distant-coast-n05516 
13 Music and literature do not furnish examples quite so easily, though it is worth noting that McBride's A Girl is a Half-Formed Thing, rejected by publishers over nine years of fruitless submissions, won the Goldsmiths' Prize, the Bailey's Prize, the Desmond Elliott Prize and the Geoffrey Faber Memorial Prize, and is undoubtedly selling well as a result (if not always being read to the end). Some of the minimalist music of Arvo Pärt might be considered both experimental and popular, though to some ears it is too bland and unadventurous to merit the former label. Size of audience is not, it seems, a fool-proof guide to what we mean by "experimental".

14 (5) The next question to be considered is: "Is experimental art always a matter of technique - of a trying-out of new forms? Or is it possible to be experimental in terms of content alone?" All the examples we have looked at so far involve formal innovation; they do not necessarily introduce material that has previously been kept out of the domain of art.

15 An artist who uses a relatively conventional form but depicts events or objects that have hitherto been excluded from art may well not be regarded as experimental. Zola represented aspects of reality that had not been the subject of fiction before him, but my sense is that we do not think of him as writing experimental novels, in spite of his own claim to be doing so (a claim based on approach (1) above, since he modelled his work on that of natural scientists). On the other hand, when there is a clear disjunction between new content and conventional form, we may reach for the idea of experimentalism to describe the work. When Mark Quinn creates a sculpture in Carrara marble representing the thalidomide victim Alison Lapper, naked and pregnant, and exhibits it on a plinth in Trafalgar Square, the contrast between the highly traditional polished marble and realistic carving and the unusual human body it represents is what makes the work powerful - and perhaps takes it into the realm of the experimental (Figure 4). 
Figure 4. Marc Quinn, Alison Lapper Pregnant (2000)

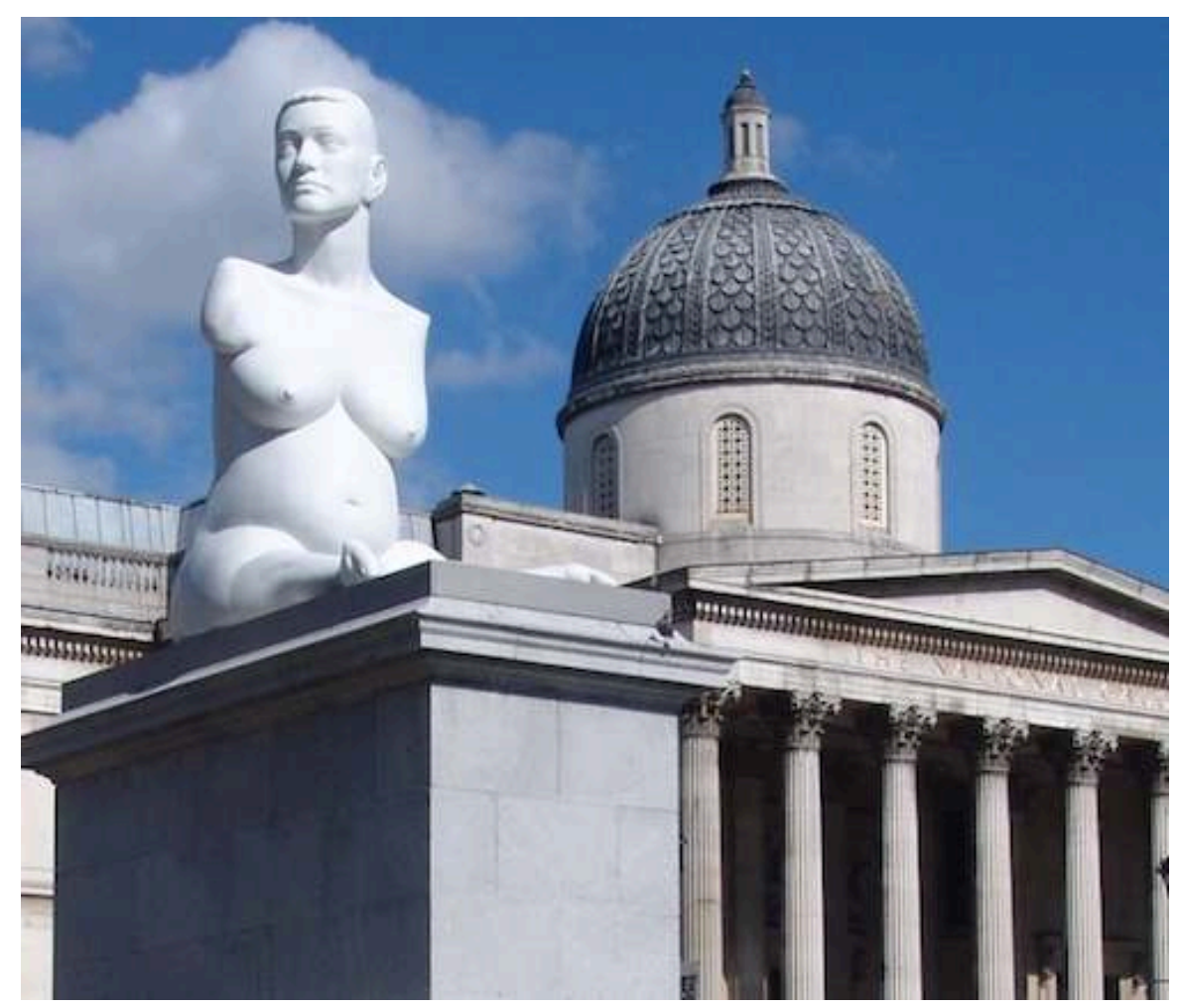

Source: http://marcquinn.com/artworks/single/alison-lapper-pregnant1

16 However, the self-assurance of Quinn's statue makes it hard to think of it as an experiment; it reads as the work of someone who knew exactly where he was going when he made it, rather than somewhat trying out an idea without knowing where it will lead. This brings us to the final question.

(6) Does experimental art as commonly understood, then, mean not fully achieved art, where the reader, listener or viewer senses the riskiness of the project in its not quite complete success? In such cases, we might feel we are sharing with the artist the trialand-error character of artistic creation, rather than receiving from his or her hand something that bears no traces of the chancy process whereby it come into being. If we return to the Matisse cut-out exhibition I mentioned earlier, we find Zoë Pilger writing in a review published in the Independent: "The early cut-outs were small, experimental" (Pilger 2014, my emphasis). 
Figure 5. Henri Matisse, The Fall of Icarus (1943)

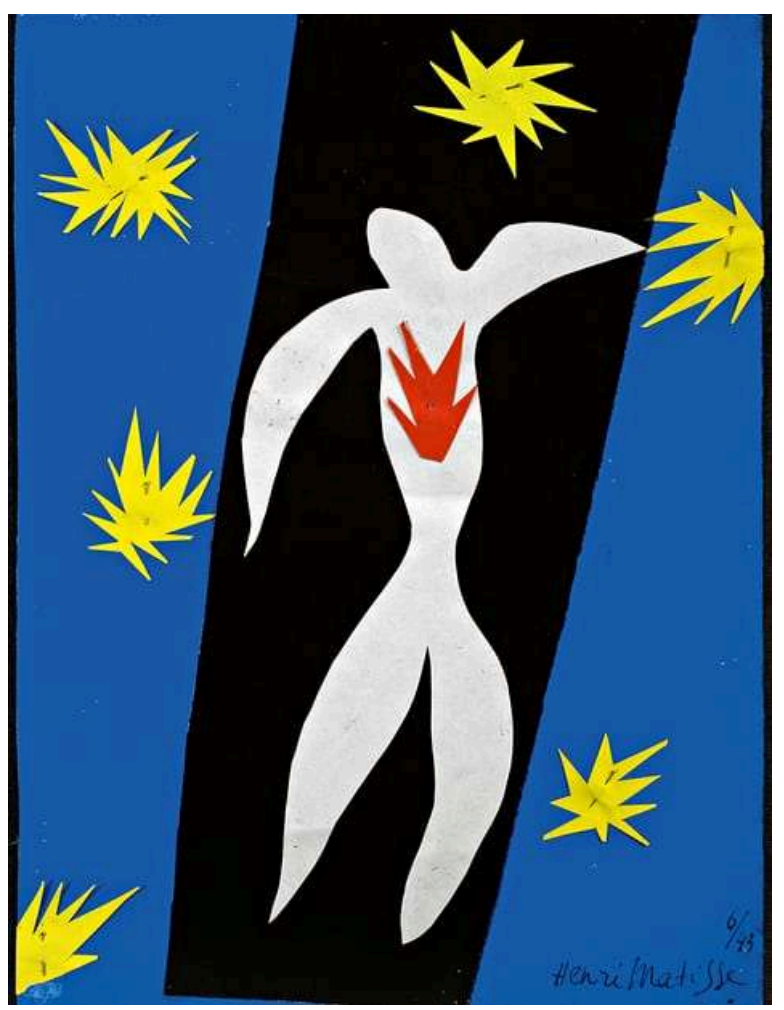

Source: https://www.theguardian.com/artanddesign/2014/mar/29/henri-matisse-cutouts-tatemodern-drawing-scissors

Presumably the later, larger, cut-outs, more suggestive of the artist's confidence in what he is doing, do not register as experimental. Colin Wilson, reviewing the late Turner exhibition, makes the opposite point: "Nor are these dozens of paintings experiments but finished works by a master" (Wilson 2014, my emphasis). For Wilson, it is the impression the works give of being finished that prevents them from being called experiments. (Richard Dorment, though, notes that "Turner experimented with octagonal and round formats and explored ever wilder colour combinations" [Dorment 2014, my emphasis]; what motivates this comment, no doubt, is that octagonal and round formats never caught on, so they remain in the realm of the unsuccessful experiment, however finished they may seem.)

We can conclude from these various uses of the term "experiment" that we do not employ it in an entirely consistent manner. The paradigmatic experimental work of art, perhaps, is one that is highly innovative in form, but does not entirely succeed in what it attempts; it bears the marks of the artist's trial-and-error procedures; it is appreciated by the few rather than the many; and it remains outside the mainstream of artistic production. But none of these criteria except the first is essential - and when we apply the term to contemporary artworks we can, as has often been noted, only do so in a provisional way: the future may turn current experiments into mainstream productions. 
I want now to set the term "experimental" next to another term, "inventive", and I will begin by quoting Jacques Derrida. Writing of the inventiveness of Francis Ponge's little poem "Fable", he says that writing such as this

\begin{abstract}
is liable to the other, open to the other and worked by it; it is writing working at not letting itself be enclosed or dominated by that economy of the same in its totality, which guarantees both the irrefutable power and the closure of the classical concept of invention. [...] Passing beyond the possible, it is without status, without law, without a horizon of reappropriation, programmation, institutional legitimation; it passes beyond the order of the demand, of the market for art or science; it asks for no patent and will never have one. (Derrida 2007: 46) ${ }^{3}$
\end{abstract}

21

This account of invention makes it sound very much like experimentation in art, challenging the status quo, going beyond the "possible", introducing that which is uncategorizable and unmarketable. But for Derrida, all art "worthy of the name" operates like this.

I find this a useful way to think about art's relation to the norms and habits that exist at the time and place of both its production and its reception. ${ }^{4}$ Invention, says Derrida, is always "invention of the other" ("invention de l'autre"), a phrase with a double genitive: the invention invents the other, but the other also invents. It is an act but also an event. In this act-event of invention, a way of doing art that is unthinkable within current norms is brought into being - an alterity that resists closure, troubles the institution, and demands new forms of attention and interpretation (and sets the critics searching for new ways of addressing - and inevitably circumscribing - the new work).

My question is this: Is it possible to distinguish between the inventiveness of all art (at least all art of any significance) and what is called experimental art? As we have seen, the term "experimental" suggests trial-and-error, the testing of new forms, the taking of risks; but isn't this true of all inventive art? Wasn't Sophocles being experimental in introducing a third actor onto the Greek stage? Wasn't Chaucer being experimental in creating a verse-form we now call iambic pentameter? Wasn't Defoe being experimental in writing a fictional narrative in the guise of an autobiography? These and many other innovations in the histories of all the arts were radical, untried, uncertain. I have already mentioned inventive works by Beethoven, Picasso, Eliot and Le Corbusier that, in the creative process, were experiments, and there are countless more examples. Only in hindsight do the new ventures by such artists appear obvious - a third actor hardly seems a surprising innovation, iambic pentameter feels like a natural verse-form in English, the novel in the guise of a fictional autobiography is hardly unusual - because they introduced new possibilities into the art form for others to take advantage of. Kant called this "exemplary originality" (Kant 1974: 150-1): not just that which has not been done before, which might be meretricious or trivial art, but that which, once done, creates fresh opportunities for new forms of originality. It is very easy to be original in the narrow sense: I could without difficulty produce a jumble of words, or sequence of sounds, or a pile of objects never before heard or seen. But these works of so-called "art" would not be inventive: they would not engage with the cultural, intellectual, political and ethical context within which they have been created, and they would not open up new possibilities for other artists. They would not, to use Derrida's words, be "open to the other".

The other, however, is not simply that which does not exist, or does not exist yet; it is other to "the economy of the same" - in other words, it is what is excluded by the 
current cultural configuration; it is what cannot be seen, or heard, or done, thanks to the power of the doxa. This is why the work of the true artist is difficult and risky: the task is to exploit the fissures and tensions within the economy of the same (which is never wholly coherent or totalised) to allow the other to be apprehended, and what that other is is not something that can be known in advance. And this is why it opens a path for future work.

It seems to me, therefore, that all art worthy of the name is experimental: all strong artists are working at the limits of what can be achieved, and all such artists are taking risks, engaging in a process of trial-and-error, going down a road without knowing where it leads. As J. M. Coetzee puts it with reference to verbal invention:

It is naïve to think that writing is a simple two-stage process: first you decide what you want to say, then you say it. On the contrary, as all of us know, you write because you do not know what you want to say. Writing reveals to you what you wanted to say in the first place. [...] What it reveals (or asserts) may be quite different from what you thought (or half-thought) you wanted to say in the first place. (Coetzee 1992: 18)

The writer of poetry, drama or fictional prose experiments with language, with what it can be made to say but also with what it can make the writer say. This is what Derrida suggests by the ambiguity of "invention de l'autre", and what I mean by the coinage "actevent". (Coetzee captures this doubleness in his apothegm, which occurs just after the passage I have quoted, "writing writes us".) The painter experiments with the possibilities of light, colour, texture and representation; the composer experiments with the possibilities of sound. And so on. The greatest artists, perhaps, are those who are most sensitive to the cultural context in which they are working (which is, of course, inseparable from the social, political and economic environment), most open to the ideas, forms, sounds, shapes and feelings it occludes and the possibilities that exist for accessing them, most daring in letting those possibilities become real in their work, and most skilled at knowing when what they are making has reached its full realization.

I believe it is right to go on calling some instances of this artistic making "experimentation", especially when it involves radically new techniques that do not become part of the central narrative of the art-form in question because they are taken up and developed by other artists. But what is also important is that we try to identify and encourage those contemporary experiments that are not merely offering something different but are engaging with the unapprehended potential that the culture has excluded - the kind of experiment that Derrida would call an invention. In the future, hindsight may strip the label "experimental" from these works precisely because they have identified so powerfully what is needed to bring to visibility, audibility or readability what the culture has excluded; they may come to seem an essential part of the story of art. We should not forget, however, that they started as experiments: ventures into the unknown, trials without guarantee of success, failures leading to new attempts, and a trust in the work that is finally delivered over to public judgement. 


\section{BIBLIOGRAPHY}

\section{Primary sources}

Atwood, Margaret. Oryx and Crake. London: Bloomsbury, 2003.

Banville, John. Book of Evidence. London: Secker and Warburg, 1989.

Catton, Eleanor. The Luminaries. London: Granta, 2013.

Danielewski, Mark Z. House of Leaves. London: Random House, 2000.

Kant, Immanuel. Critique of Judgment. London: Collier Macmillan Publishers, 1974.

McBride, Eimear. A Girl is a Half-Formed Thing. Norwich: Galley Beggar Press, 2013.

Self, Will. Umbrella. London: Bloomsbury, 2012.

Smith, Ali. How to Be Both. London: Hamish Hamilton, 2014.

Tóibín, Colm. The Master. London/New York: Picador, 2004.

\section{Secondary sources}

Attridge, Derek. Well-weighed Syllables: Elizabethan Verse in Classical Metres. Cambridge: Cambridge UP, 1974.

Attridge, Derek. The Singularity of Literature. Abingdon: Routledge, 2004.

Attridge, Derek. The Work of Literature. Oxford: Oxford UP, 2015.

Coetzee, J. M. Doubling the Point. David Attwell, ed. Cambridge: Harvard UP, 1992.

Derrida, Jacques. “Psyché: Invention de l'autre.” In Psyché: Inventions de l'autre. Paris: Galilée, 1987. Derrida, Jacques. "Psyche: Invention of the Other." In Psyche: Inventions of the Other. Peggy Kamuf and Elizabeth Rottenberg, eds. Stanford: Stanford UP, 2007.

\section{Websites}

Dorment, Richard. “Late Turner: Painting Set Free, review: 'Don't let's get too sentimental about Turner'.” The Telegraph. 8 September 2014. http://www.telegraph.co.uk/culture/art/art-reviews/ 11081456/Late-Turner-Painting-Set-Free-review-Dont-lets-get-too-sentimental-aboutTurner.html

Pilger, Zoe. "Henri Matisse: The Cut-Outs, Tate Modern, art review." The Independent. 14 April 2014. http://www.independent.co.uk/arts-entertainment/art/reviews/henri-matisse-thecutouts-tate-modern-art-review-9259383.html Synergy Project. http://science360.gov/obj/video/698ddccc-3558-40bd-a52e-bad1e90bf019/ synergy-project-light-life 


\section{NOTES}

1. For a full discussion, see Attridge (1974). The movement had analogues in a number of other European countries, including France, Germany, Italy and Spain.

2. This is not to suggest that later artists have not been influenced by these experiments, but they cannot be said to have initiated artistic movements when displayed. Later artists - the abstract expressionists of the 1940s and 1950s in the case of late Turner and the minimalists of the 1960s in the case of Malevich - may be seen to have built on them, but this does not lessen their experimental status in their own time.

3. Translation modified. The original French reads: "Cette écriture est passible de l'autre, ouverte à l'autre et par lui, par elle travaillé, travaillant à ne pas se laisser enfermer ou dominer par cette économie du même en sa totalité, celle qui assure à la fois la puissance irréfutable et la fermeture du concept classique d'invention. [...] Passant au-delà du possible, elle est sans statut, sans loi, sans horizon de réappropriation, de programmation, de légitimation institutionnelle, elle passe l'ordre de la commande, du marché de l'art ou de la science, elle ne demande aucun brevet et n'en aura jamais." (Derrida 1987: 61)

4. I have developed the notion of invention in The Singularity of Literature (Attridge 2004) and The Work of Literature (Attridge 2015).

\section{ABSTRACTS}

This essay explores and evaluates a number of possible ways in which the phrase "experimental art" might be understood, considering several particular examples. "Experimental" may be understood purely on the basis of the scientific model, though this is not what we usually mean by the term. The experimental quality of art is more likely to be understood as a matter of degree of innovation, though this approach is rendered problematic when put in a historical context. We are more liable to call something an experiment when it does not lay the foundations for a new movement, but is something of a dead-end. It may be thought that the size of the audience is important, experimental art often being of minority interest, but some counter-examples are cited. The next question the essay considers is: "Is experimental art always a matter of technique - of a trying-out of new forms? Or is it possible to be experimental in terms of content alone?" Experimental art as commonly understood often means not fully achieved art. The essay then sets the term "experimental" next to another term, "inventive", drawing on the work of Jacques Derrida. Inventive art is very like experimental art, challenging the status quo, going beyond the "possible", introducing that which is uncategorizable and unmarketable. The paradigmatic experimental work of art, perhaps, is one that is highly innovative in form, but doesn't entirely succeed in what it attempts; it bears the marks of the artist's trial-and-error procedures; it is appreciated by the few rather than the many; and it remains outside the mainstream of artistic production.

Cet article explore et évalue les différentes manières de comprendre l'expression "l'art expérimental", en se basant sur des exemples précis. "Expérimental" peut être entendu comme étant entièrement basé sur un modèle scientifique, même si ce n'est pas ainsi qu'on l'entend habituellement. La qualité expérimentale de l'art est cependant beaucoup plus liée à un degré d'innovation qu'elle introduit, bien que cette approche puisse être problématique quand on la 
replace dans un contexte historique. Il est plus probable que nous désignions une œuvre comme "expérimentale" quand elle ne pose pas les fondations d'un nouveau mouvement, mais qu'elle représente plutôt une impasse. On peut penser que l'ampleur du public qui l'apprécie est importante, l'art expérimental n'étant souvent intéressant que pour une minorité de personnes, mais on peut trouver des contre-exemples. La question que se pose ensuite l'article est la suivante : «est-ce que l'art expérimental est toujours une question de technique, d'expérimentation autour de formes nouvelles? Ou bien est-il possible d'être expérimental seulement au niveau du contenu? " L'art expérimental tel qu'on le conçoit d'ordinaire est souvent un art qui n'est pas totalement achevé. L'article confronte le terme d' "expérimental » avec celui d'« inventif », en se basant sur l'œuvre de Jacques Derrida. L'art inventif est très semblable à l'art expérimental, il remet en question le status quo, va au-delà des possibles, introduit ce qui n'est pas catégorisable ni commercialisable. L'œuvre d'art expérimentale paradigmatique est peut-être celle qui est très innovante au niveau formel mais ne réussit pas tout à fait à atteindre le but recherché. Elle porte la marque de la procédure de tâtonnement de l'artiste, elle est appréciée par quelques-uns plutôt que par le plus grand nombre, et elle reste en dehors de la production artistique standard.

\section{INDEX}

Keywords: experimental art, science, technique, risk, inventiveness, Derrida Jacques, art, literature

Mots-clés: art expérimental, science, technique, risque, inventivité, Derrida Jacques, art, littérature

\section{AUTHOR}

\section{DEREK ATTRIDGE}

Derek Attridge is the author of, among other books, Peculiar Language: Literature as Difference from the Renaissance to James Joyce (Cornell, 1988), Poetic Rhythm: An Introduction (Cambridge, 1995), The Singularity of Literature (Routledge, 2004; reissued as Routledge Classic, 2017), Moving Words: Forms of English Poetry (Oxford, 2013), and The Work of Literature (Oxford, 2015). He is the editor of Jacques Derrida's Acts of Literature (Routledge, 1992) and collections of essays on literary theory, James Joyce, and South African literature. Forthcoming is The Experience of Poetry: From Homer's Listeners to Shakespeare's Readers. Having taught at Oxford, Southampton, Strathclyde and Rutgers Universities, he is now Emeritus Professor at the University of York, and a Fellow of the British Academy. Contact: derek.attridge[at]york.ac.uk 